\title{
Comparative study of conventional and enzymatic pretreatment (scouring \& bleaching) of cotton knitted fabric
}

\author{
Abu Bakar Siddiquee*, Md. Mahbubul Bashar, Priti Sarker, Tanzina Tasmina Tohfa, Md. Amjad Hossan, \\ Md.Ibrahim Azad, Nazma Akhtar
}

Department of textile engineering, Mawlana bhashani science \& technology university, santosh, tangail-1902. Bangladesh

*Corresponding author E-mail: bakarsiddiquee_69@yahoo.com

Copyright () 2014 Abu Bakar Siddiquee et al. This is an open access article distributed under the Creative Commons Attribution License, which permits unrestricted use, distribution, and reproduction in any medium, provided the original work is properly cited.

\begin{abstract}
The scouring and bleaching performance of conventional process (hydrogen peroxide, sodium hydroxide), was compared to that of enzymatic process using enzyme (arylesterase) which catalyst the discontinuous peroxide reaction. The whiteness and reflectance $\%$ indicating bleaching performance and absorbency and weight loss \% was used as a measure of the scouring performance. Comparison of these performance and the effects are analyzed by using graphical representation. The weight loss $\%$ of enzymatic process was less than conventional process. In conventional process the reflectance $\%$ and absorbency increased and whiteness decreased with the increasing of concentration of caustic soda and the aforementioned properties were increased with the increasing of concentration of $\mathrm{H}_{2} \mathrm{O}_{2}$. In enzymatic process the reflectance $\%$ of cotton fabric increased and whiteness and absorbency fluctuated with the increasing of concentration of enzyme. Meanwhile reflectance \%, absorbency and whiteness increased with the increasing of concentration of hydrogen peroxide. Enzymatic process was found eco-friendly process as it was occurred in neutral $\mathrm{pH}$ and the COD of this process was less than conventional process. It was found that the enzymatic process was superior to the conventional process under the conditions studied.
\end{abstract}

Keywords: Scouring, bleaching, conventional, enzymatic pretreatment.

\section{Introduction}

Scouring and bleaching is the most important wet processes applied to textile materials before dyeing and printing. It is mostly cleaning and whitening process in which all impurities and natural colors are removed. The impurities may be natural or added. When the impurities are removed, the cotton becomes absorbent [1]. More specifically scouring and bleaching is done in order to remove or destruction of natural and adventitious coloring maters and unwanted oils, fats, waxes, soluble impurities and any particulate or solid dirt adhering to the fibers, which otherwise hamper dyeing, printing and finishing processes [2]. In the conventional preparatory process concentrated sodium hydroxide solution and hydrogen peroxide are applied for removing the impurities from raw cotton. Generally, 5-10\% weight loss occured and a dramatic improvement in wettability and absorbency are achieved for the action of scouring process for natural cellulosic fibres [3]. In aqueous solution, hydrogen peroxide is ionized into perhydroxyl and hydrogen ions [2].The perhydroxyl ion is the active bleaching agent. It reacts with the natural color material of cellulose and destroys them. Strong alkaline condition (pH $10.5-10.8$ ) is optimum in bleaching process [2].

The conventional scouring process is associated with harsh chemicals which is detrimental to environment. This process is slowly being replaced with environment friendly approach using enzymes. These enzymes remove the non-cellulosic impurities present in the fabric. Such a process would enhance the absorbency of the fabric without appreciable strength loss and also would help in the proper dyeing and finishing of the fabric.

The application of enzymes has many advantages compared to conventional process. It can be used in catalytic concentrations at low temperatures and at $\mathrm{pH}$-values near to neutral. Enzymes are biologically degradable and can be 
handled without risk [4], [5]. The enzymatic process on cotton indicates about $25 \%$ lower climate change impact compared to a conventional bleaching process [6].

The mechanism of enzymatic bleaching has the following reactions [7]:

Activated, enzymatic peroxide bleach:

Per hydrolase:

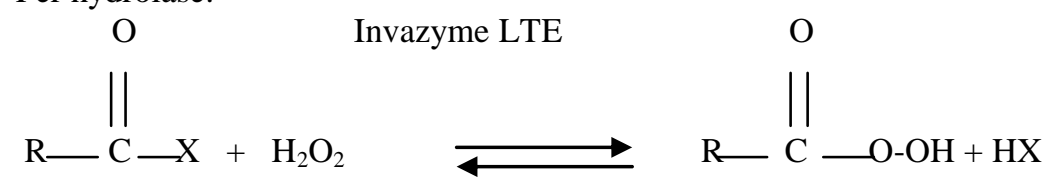

Activator

Peracid

Invatex LTA

Bleaching reactions:

$\mathrm{O}$<smiles>[R]C(=C)OO</smiles>

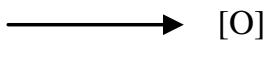

$+$

Active oxygen<smiles>[R]C(=O)O</smiles>

Peracid Bleached fibre

$[\mathrm{O}]+$ Fibre

Carboxylic acid

In this research work Gentle Power Bleach, a joint-venture product from Huntsman and Genencor was used. The novel enzyme allows for the system to perform at much lower temperatures for bleaching and at neutral $\mathrm{pH}$ levels. The investigation is carried out at $65^{\circ} \mathrm{C}$ and different properties such as whiteness, weight loss $\%$, COD value of the effluent have studied and compared with conventional one.

\section{Experimental}

\subsection{Materials:}

$100 \%$ cotton single jersey fabric of GSM 160 was collected from Unitex group was used in this investigation. The chemicals used for this project are listed in table 1.

Table 1: Lists of chemicals

\begin{tabular}{ll}
\hline Conventional process & Enzymatic process \\
\hline Alkali $(\mathrm{NaOH}$ commercial grade) & Alkali ( Soda ash commercial grade) \\
$35 \% \mathrm{H}_{2} \mathrm{O}_{2}$ & $35 \% \mathrm{H}_{2} \mathrm{O}_{2}$ \\
Stabilizer (Clarite CBB) & CLARITE LTC \\
Detergent (Imvacline DA) & INVATEX LTA \\
& INVAZYME LTE(enzyme) $^{\text {a }}$ \\
\hline
\end{tabular}

A. combination product of wetting, detergent and dispersing $b$. agent to assist and boost the peroxide reaction

All the chemicals were supplied by Swiss Colours Bangladesh Ltd. (HUNTSMAN)

\subsection{Recipe:}

For processing the samples AHIBA NUANCE and IR sample dyeing machine were used. Table 2 and Table 3 show the recipe for processing the samples.

Table 2: Recipe of conventional process (A.Hydrogen peroxide variation B. Caustic soda variation)

\begin{tabular}{lll}
\hline Sample & $\mathrm{H}_{2} \mathrm{O}_{2}(\mathrm{~g} / \mathrm{l})$ & $\mathrm{NaOH}(\mathrm{g} / \mathrm{l})$ \\
\hline A. Variation in $\mathrm{H}_{2} \mathrm{O}_{2}$ & \multicolumn{2}{l}{} \\
Sample-1 & 2 & 3 \\
Sample-2 & 4 & 3 \\
Sample-3 & 6 & \\
B. Variation in $\mathrm{NaOH}$ & & 2 \\
Sample-1 & 4 & 4 \\
Sample-2 & 4 & 6 \\
Sample-3 & 4 & \\
\hline
\end{tabular}


For Table 2 detergent $1(\mathrm{~g} / \mathrm{l})$ and stabilizer $0.2(\mathrm{~g} / \mathrm{l})$ were used for every sample.

Table 3: Recipe of enzymatic process (A.Hydrogen peroxide variation B. Enzyme variation)

\begin{tabular}{lcc}
\multicolumn{4}{c}{ Table 3: Recipe of enzymatic process (A.Hydrogen peroxide variation B. Enzyme variation) } \\
\hline Sample & $\mathrm{H}_{2} \mathrm{O}_{2}(\mathrm{~g} / \mathrm{l})$ & Invazyme LTE $(\mathrm{g} / \mathrm{l})$ \\
\hline A. Variation in $\mathbf{H}_{2} \mathbf{O}_{2}$ & & \\
Sample-1 & 4 & 1 \\
Sample-2 & 6 & 1 \\
Sample-3 & 9 & 1 \\
B. Variation in concentration of enzyme & & \\
Sample-1 & 6 & 0.5 \\
Sample-2 & 6 & 1.5 \\
Sample-3 & 6 & 2 \\
Sample-4 & 6 & 2.5 \\
Sample-5 & 6 & 3 \\
\hline
\end{tabular}

For Table 3 Invatex LTA $3(\mathrm{~g} / \mathrm{l})$, soda ash $2(\mathrm{~g} / \mathrm{l})$ and Clarite LTC $1.5(\mathrm{~g} / \mathrm{l})$ were used for every sample.

At first bath was prepared according to recipe. $50 \mathrm{ml}$ of the solution were taken from the bath in every pot and then $5 \mathrm{gm}$ of fabric immerged into the solution in each pot. Then the pots were set into an infrared lab sample dyeing machine. The machine program was set. The machine was run $60 \mathrm{~min}$ for conventional process at $98^{\circ} \mathrm{C}$ and 40 min for enzymatic process at $65^{\circ} \mathrm{C}$. Then the samples were neutralized with $0.5 \mathrm{~g} / \mathrm{l}$ acetic acid only for conventional process. After hot wash, cold wash and rinsing the samples were dried in a dryer. Then whiteness and reflectance were measured by a spectrophotometer and absorbency was tested by drop and column test.

\subsection{Estimation of scouring effect:}

1) Determination of weight loss

The weight of unscoured and scoured samples was taken separately at the same moisture content and then the weight loss is measured in percentage.

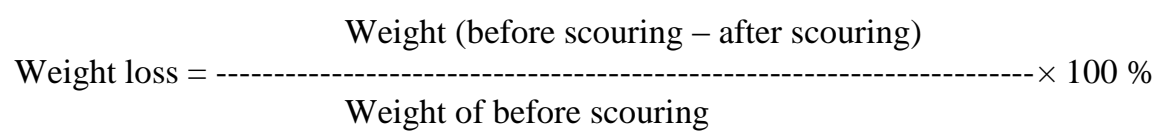

For each recipe 3 samples were taken. Mean value of weight of these 3 unscoured fabric and scoured fabric were taken and from above equation weight loss $\%$ were measured.

2) Absorbency Test

The absorbency was measured by using Column test or Wicking test [2].

\subsection{Estimation of bleaching effect:}

1) Measurement of reflectance and whiteness

The CIE Whiteness Index (WI) value and reflectance were measured according to AATCC Test Method 110-1995 [8]. The whiteness and reflectance were measured using a Datacolor Spectrophotometer SF 600X with the following settings: illuminant D65, large area view, specular included and CIE 1964 Supplemental Standard Observer (10 observer). Each sample was folded twice to give an opaque sample and the whiteness and reflectance were measured.

\subsection{Effluent Test:}

Chemical Oxygen Demand (COD) was determined by Dichromate Reactor Digestion Method.

\section{Results and discussions}

\subsection{Analysis of weight loss \%:}

Fig. 1 shows the weight loss $\%$ of the samples processed in conventional pretreatment method. Various concentrations of caustic soda and $\mathrm{H}_{2} \mathrm{O}_{2}$ were used. The weight loss \% was observed 4.75\%, 5.77\%, 5.73\% for 2, 4, $6 \mathrm{~g} / \mathrm{l} \mathrm{NaOH}$ and $4.55 \%, 2.98 \%, 4.35 \%$ for $2,4,6 \mathrm{~g} / 1 \mathrm{H}_{2} \mathrm{O}_{2}$. 
(a) Caustic Soda Variation

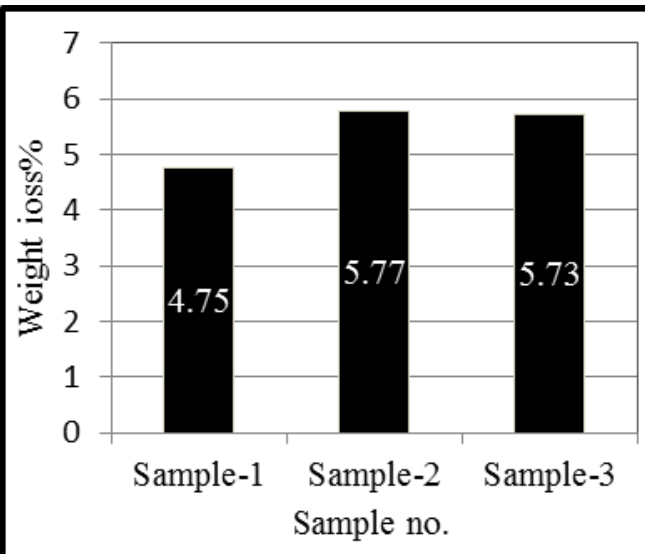

(b) $\mathrm{H}_{2} \mathrm{O}_{2}$ variation

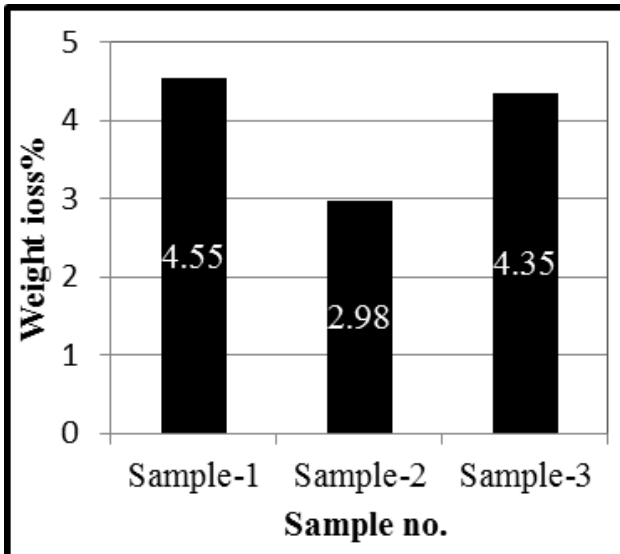

Fig. 1: Weight loss (\%) of samples in conventional process (a) Caustic Soda Variation (b) $\mathrm{H}_{2} \mathrm{O}_{2}$ variation.

Fig. 2 shows the weight loss $\%$ of the samples processing in enzymatic pretreatment process. The concentration of $\mathrm{H}_{2} \mathrm{O}_{2}$ varied as 4, 6, $9 \mathrm{~g} / \mathrm{l}$ and weight loss recorded $3.16 \%, 2.78 \%, 3.95 \%$ respectively. The concentration of enzyme varied as $0.5,1.5,2,2.5,3 \mathrm{~g} / \mathrm{l}$ and weight loss recorded $3.54 \%, 2.96 \%, 3.56 \%, 2.97 \%$, and $2.57 \%$ respectively. From the result it is seen that, in case of enzymatic scouring bleaching with both types of variation weight loss $\%$ is lower.

(a) Enzyme Variation

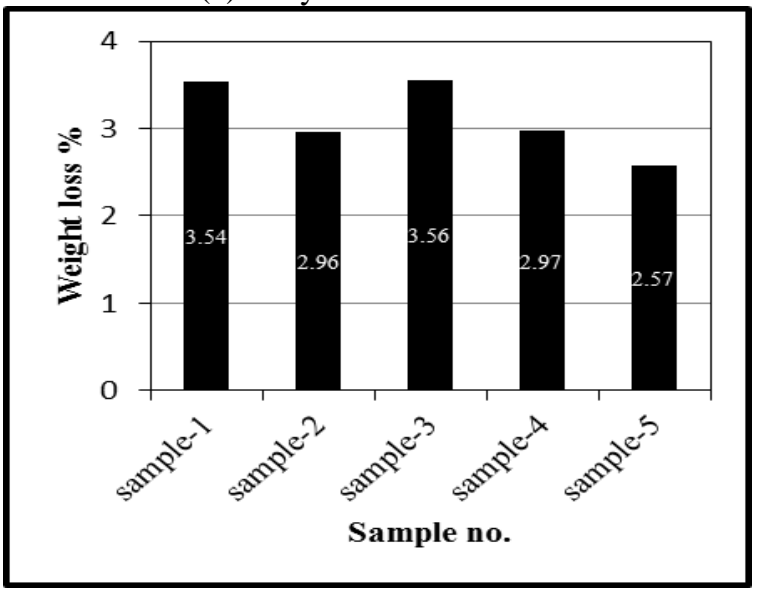

(b) $\mathrm{H}_{2} \mathrm{O}_{2}$ variation

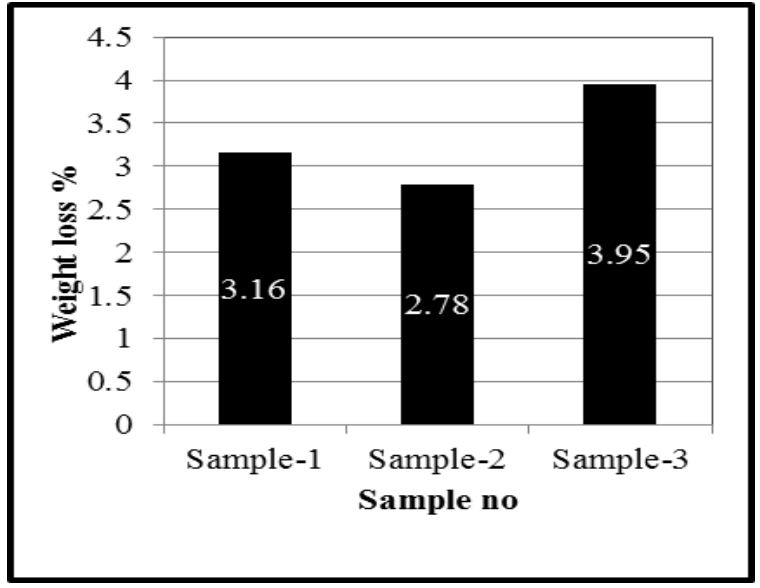

Fig. 2: Weight loss (\%) of samples in enzymatic process (a) Enzyme Variation (b) $\mathrm{H}_{2} \mathrm{O}_{2}$ variation.

In conventional process the weight loss $\%$ in different concentration of caustic soda is more than different concentration of hydrogen peroxide. In enzymatic process the result of weight loss $\%$ is near to close in different concentration of enzyme and hydrogen peroxide. In comparison with fig. 1 and fig. 2 it is seen that weight loss $\%$ of samples in enzymatic process is much less than conventional process in both types of variation.

\subsection{Analysis of reflectance\%:}

Fig. 3 shows the reflectance curve of samples with caustic soda variation in conventional process. It is seen that, in case of sample-3, the reflectance value is highest $(83 \%)$ for the fabric processed with $6 \mathrm{~g} / \mathrm{l} \mathrm{NaOH}$ and in case of sample -01 ; reflectance value is lowest $(81.58 \%)$ with $2 \mathrm{~g} / \mathrm{l} \mathrm{NaOH}$. It is evident that reflectance\% increase with the increase in $\mathrm{NaOH} \%$. 


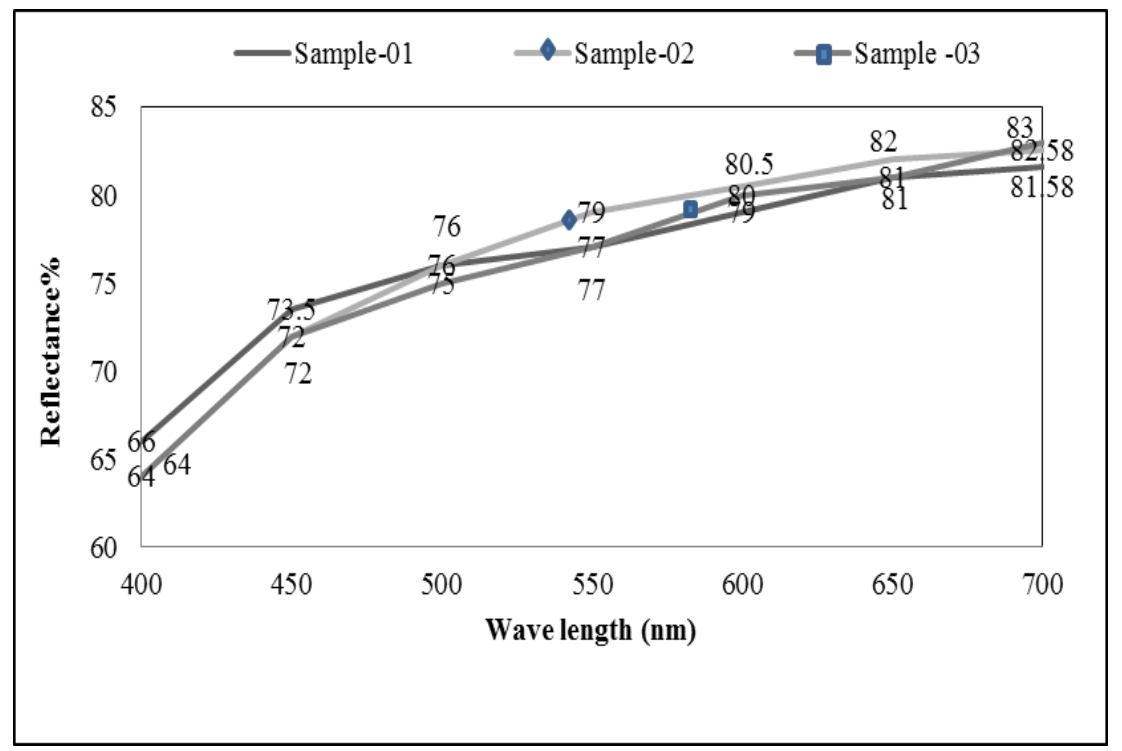

Fig. 3: Reflectance curve of samples with caustic soda variation in conventional process

Fig. 4 shows the reflectance curve of samples with hydrogen peroxide variation in conventional process. It is seen that, in case of sample-3, the reflectance value is highest (83\%) for the fabric processed with $4 \mathrm{~g} / \mathrm{l} \mathrm{H}_{2} \mathrm{O}_{2}$ and in case of sample-2; reflectance value is lowest (82.5\%) with $3 \mathrm{~g} / \mathrm{l} \mathrm{H}_{2} \mathrm{O}_{2}$.

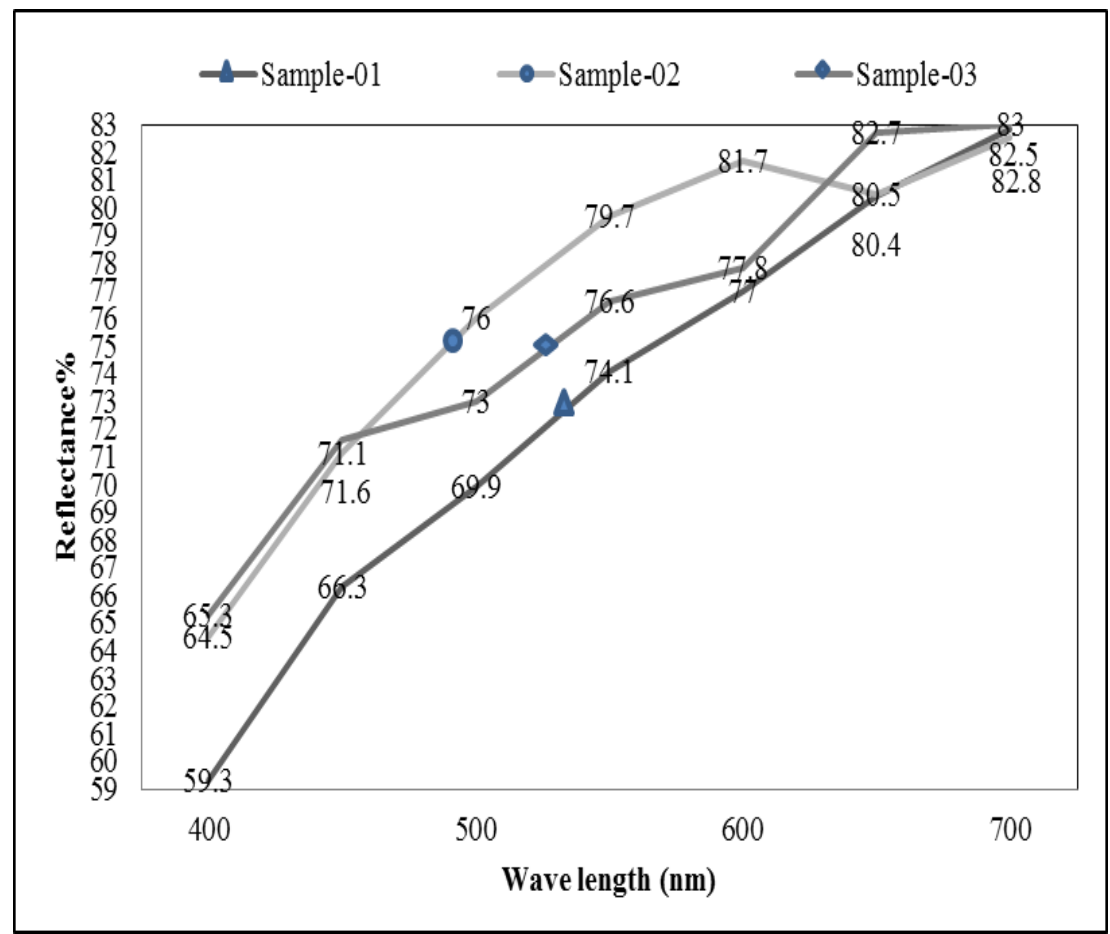

Fig. 4: Reflectance curve of samples with hydrogen peroxide variation in conventional process

Fig. 5 shows the reflectance curve of samples with enzyme variation in enzymatic process. It can be seen from the graph that, in case of sample-5 the reflectance value is highest $(86.8 \%)$ for the fabric processed with $3 \mathrm{~g} / \mathrm{l}$ enzyme and in case of sample- 1 reflectance value is lowest $(82 \%)$ with $0.5 \mathrm{~g} / 1$ enzyme. 


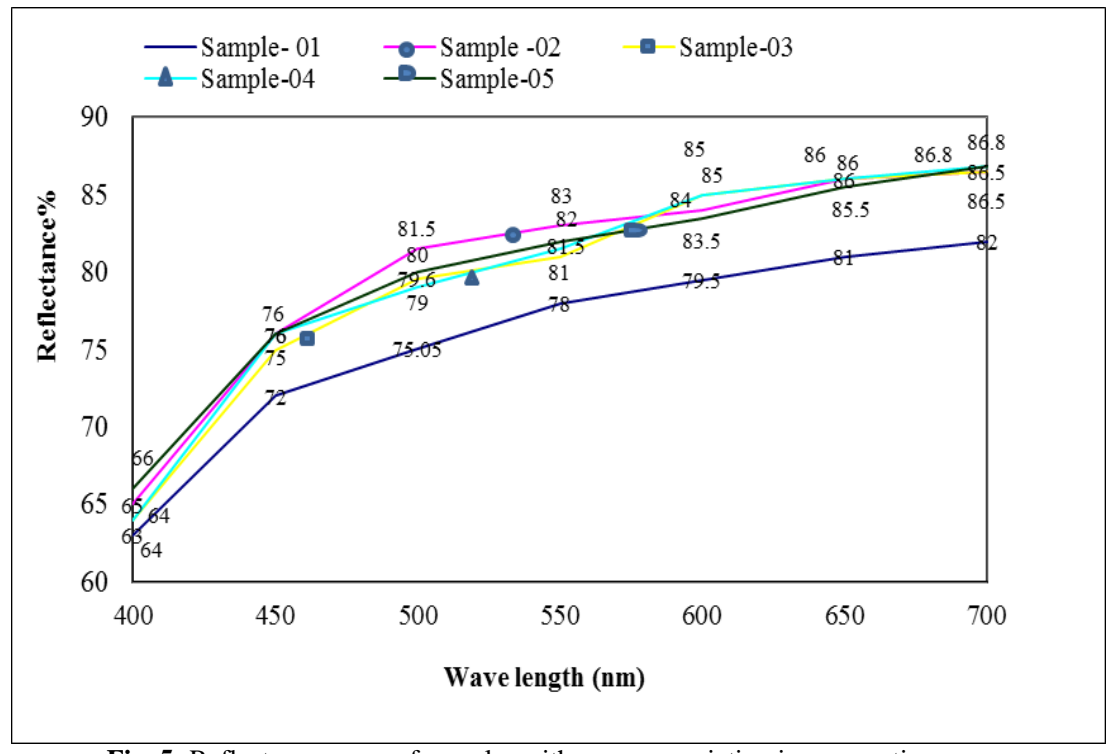

Fig. 5: Reflectance curve of samples with enzyme variation in enzymatic process

Fig. 6 shows the reflectance curve of samples with peroxide variation in enzymatic process. It can be seen from the graph that, in case of sample-3 the reflectance value is highest (84.6\%) for the fabric processed with $9 \mathrm{~g} / 1 \mathrm{H}_{2} \mathrm{O}_{2}$ and in case of sample-1 reflectance value is lowest (83.7\%) with $4 \mathrm{~g} / \mathrm{l} \mathrm{H}_{2} \mathrm{O}_{2}$.

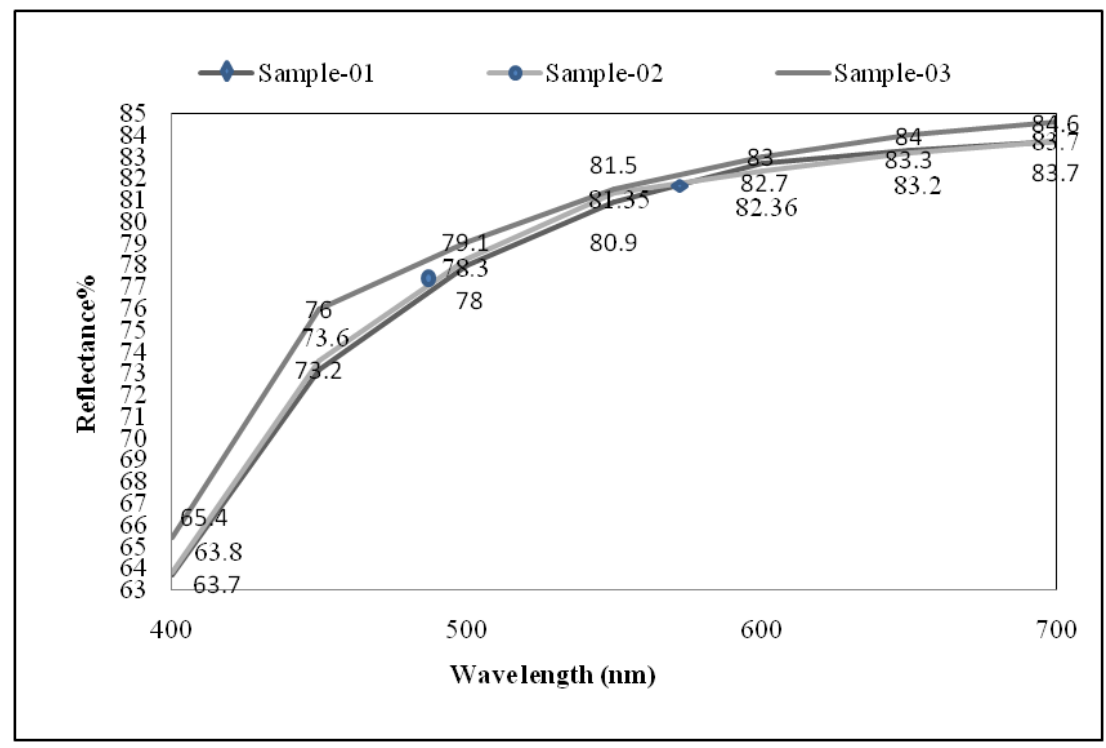

Fig. 6: Reflectance curve of samples with hydrogen peroxide variation in enzymatic process

In comparison with fig. 3, 4 and fig. 5, 6 it is said that the reflectance\% of samples treated with enzymatic process is more than conventional process.

\subsection{Analysis of whiteness index}

Table 4: Whiteness index (WI) of samples both of conventional and enzymatic pretreatment process

\begin{tabular}{lllll}
\hline Sample & \multicolumn{2}{c}{ WI of Conventional Process } & \multicolumn{2}{c}{ WI of Enzymatic Process } \\
\hline & $\mathrm{NaOH}$ variation & $\mathrm{H}_{2} \mathrm{O}_{2}$ variation & Enzyme variation & $\mathrm{H}_{2} \mathrm{O}_{2}$ variation \\
Sample-1 & 58.12 & 45.15 & 53.12 & 54.25 \\
Sample-2 & 53.12 & 57.74 & 54.99 & 55.08 \\
Sample-3 & 51.75 & 58.96 & 54.64 & 57.08 \\
Sample-4 & & & 53.62 & \\
Sample-5 & & & 56.84 & \\
\hline
\end{tabular}

The whiteness index of samples both of conventional and enzymatic pretreatment process with different concentration of hydrogen peroxide, caustic soda and enzyme are listed in Table 4. 
It shows that, in conventional pretreatment process when the concentration of hydrogen peroxide increases the whiteness value also increases and when the concentration of sodium hydroxide or caustic soda increases the whiteness value decreases. Meanwhile, in enzymatic pretreatment process when the concentration of enzyme increases the whiteness value certain time increases and certain time decreases but the best result is found in sample-5 with $3 \mathrm{~g} / \mathrm{l}$ enzyme and when the concentration of hydrogen peroxide increases the whiteness value also increases.

In comparison with conventional and enzymatic process in terms of whiteness index it is said that whiteness of the samples of enzymatic process superior to conventional process.

\subsection{Analysis of absorbency by column test:}

Table 5: Column test of samples both of conventional and enzymatic pretreatment process

\begin{tabular}{|c|c|c|c|c|}
\hline \multirow[t]{2}{*}{ Sample } & \multicolumn{2}{|c|}{ Color Raise $(\mathrm{mm})$ in Conventional Process } & \multicolumn{2}{|c|}{ Color Raise $(\mathrm{mm})$ in Enzymatic Process } \\
\hline & $\mathrm{NaOH}$ variation & $\mathrm{H}_{2} \mathrm{O}_{2}$ variation & Enzyme variation & $\mathrm{H}_{2} \mathrm{O}_{2}$ variation \\
\hline Sample-1 & 28 & 25 & 40 & 32 \\
\hline Sample-2 & 42 & 35 & 50 & 47 \\
\hline Sample-3 & 45 & 42 & 40 & 39 \\
\hline Sample-4 & & & 50 & \\
\hline Sample-5 & & & 50 & \\
\hline
\end{tabular}

Table 5 shows the absorbency (column test) of samples both of conventional and enzymatic pretreatment process with different concentration of hydrogen peroxide, caustic soda and enzyme where the measurement is assessed by the raise of $0.1 \%$ direct red solution in $\mathrm{mm}$ at $5 \mathrm{~min}$. It is seen from the table 4 that, the fabric becomes more absorbent in case of enzymatic scouring process and enzyme variation records the highest color raise. From the data it is evident that there is a little effect in $\mathrm{H}_{2} \mathrm{O}_{2}$ variation. Moreover, overall absorbency of enzymatic process is better than the conventional one.

\subsection{Analysis of COD test}

In enzymatic process the value of COD of effluent is found $2518 \mathrm{mg} / \mathrm{l}$ and in conventional process the value of COD of effluent is found $5161 \mathrm{mg} / \mathrm{l}$. This result shows that the value of COD in conventional process is almost double to enzymatic process. So, the effluent from conventional process is more detrimental to the environment.

\section{Conclusion}

This investigation revealed that the fabrics found from the enzymatic scouring bleaching process show more softer handle and much less weight loss\% than conventional process. The reflectance\%, whiteness index and absorbency of enzymatic process were same. From the effluent test result it is found the enzymatic process has less adverse impact on environment. It can be said that enzymatic process will play a vital role in future textile processing. This investigation recommended in further research for developing pretreatment process in bulk production.

\section{Acknowledgements}

The authors acknowledge the Swiss Colours Bangladesh Ltd. (HUNTSMAN) for providing lab facilities to complete the study. The authors give special and cordial thanks to HUNTSMAN.

\section{References}

[1] V. A. Shenai, Technology of Textile Processing, vol. III,(Bombay ,1991), pp. 80,180.1991.

[2] S. R. Karmakar, Chemical technology in the pretreatment processes of textiles, Textile Science and Technology Series, 1st Ed., ISBN 0-444500060-X, Elesevier Science B.V., Amsterdam, the Netherlands, pp. 86, 170,453. 1999.

[3] W. S. Hickman, Preparation (Vol. Cellulosics Dyeing), (J. Shore, Ed.) England: Society of Dyers and Colourists, pp. 110.1995.

[4] H. Uhlig, Enzyme arbeiten für uns, C. Hanser Verlag, München.1991.

[5] H. Ruttloff, Industrielle Enzyme, Behr's Verlag, Hamburg.1994.

[6] Documentary reports of Gentle Bleaching, Huntsman, available at: www.huntsman.com

[7] S. Hossain, and K.Uddin, International Journal of Engineering \& Technology IJET-IJENS, vol. 11, no: $03,2011$.

[8] AATCC Technical Manual, vol. 75 (Research Triangle Park: AATCC, 2000). 